\title{
Response of red roomy grapevines to spray of orthophosphoric acid and copper sulphate
}

\author{
Mansour A.E.M., Laila F. Hagagg, M.A. Merwad and M.S. El-Shamma \\ Pomology Department, Agricultural \& Biological Research Division, National Research Centre (NRC), \\ 33 El-Buhouth St., 12622 Dokki, Giza, Egypt.
}

Received: 10 Oct. 2020 / Accepted 15 Nov. 2020 / Publication date: 30 Nov. 2020

\begin{abstract}
In a private vineyard located at Aga district, Dakahlia Governorate, forty two head trained Red Roomy grapevines 17 years old to study the effect of four sprays of orthophosphoric acid and /or copper sulphate each at 0.1 or $0.2 \%$ on yield and quality of Red Roomy grapes during 2018 and 2019 seasons. Results showed that single or combined application of such two fertilizers was very effective in improving berry set, yield as well as physical and chemical properties of the berries. Meaningless effect on such parameters was observed due to raising their concentrations from 0.1 to $0.2 \%$. Spraying orthophosphoric acid surpassed the application of copper sulphate on improving the productivity of the vines. For obtaining the highest economical yield and improving quality of berries, it is recommended to spray Red Roomy grapevines with orthophosphoric acid plus copper sulphate four times at 0.1 $\%$ per each. The relative increases in yield/vine were about 89.6 and $123.0 \%$ for spraying orthophosphoric acid with copper sulphate each at $0.1 \%$ than unsprayed vines in the 2018 and 2019 seasons, respectively.
\end{abstract}

Keywords: Orthophosphoric acid, copper sulphate, yield, quality and grapevines.

\section{Introduction}

Grape is considered as an important food in human nutrition. It is easily assimilated because it mostly consists of carbohydrate in the form of monosaccharides like glucose and fructose. Moreover, grape contains minerals such as potassium, phosphorus, magnesium, iron and calcium. In addition, it contains different vitamins such as $\mathrm{A}_{,} \mathrm{B}_{2}$ and $\mathrm{B}_{6}$ (Ustun and Tosun, 1997).

Phosphorus is one of the most important elements for plant growth and development. It is a key for life because it has specific and direct role in most plant processes. The role of phosphorus is critical since it is associated with photosynthesis, cell formation and division of living cells, transmission of living traits and genetic traits since it is a component of nucleic acids (DNA and RNA). Further, phosphorus in addition to protein, involves in formation of cellular membranes such as plasma and the vacuole membrane. Moreover, it plays a vital role in the stimulated root development such as the formation of seminal and hair roots as well as increasing stalk, stem strength and resistance to plant diseases (Havlin et al., 2005).

Singh et al. (2005) showed that spraying mango tree with phosphoric acid at $2 \%$ gave the highest values of fruit weight, pulp/ stone ratio, yield/tree, TSS, TSS/acid ratio and total sugars than unsprayed plants. Spraying phosphoric acid at $0.3 \mathrm{ml} /$ liter at full bloom + fruit set significantly increased fruit weight, fruit length, fruit diameter, fruit firmness and yield as well as total soluble solids, titratable acidity and T.S.S/acid ratio with lowest values of percentage of total sugars in Le-Conte pear (Asad et al. 2013). In addition, Davarpanah et al. (2017) indicated that spraying pomegranate with Mixture of di-potassium phosphate at $2000 \mathrm{mg} / \mathrm{l}$ increased fruit yield, number of fruits per tree and fruit size. However, Noori et al. (2018) showed that spraying grape with phosphorus at $10 \mathrm{~g} / 1$ was the best treatment for enhancing cluster number and cluster weight, fruit number / cluster, TSS and total acidity than $5 \mathrm{~g} / 1$ or unsprayed.

Copper has an important role in plants. It was found in all parts of the plant and has the highest concentration in seed embryos. Copper concentration ranged between 20-30 ppm in the dry matter of plants. It is a vital micronutrient for plant growth and development and detrimental to photosynthetic membranes (Maksymiec, 1997). It is needed in small quantities and lack of copper led to yield reduction

Corresponding Author: Mansour, A.E.M., Pomology Department, Pomology Department, Agricultural \& Biological Research Division, National Research Centre (NRC), 33 El-Buhouth St., 12622 Dokki, Giza, Egypt. E-mail: amansourus@yahoo.com 
while excess copper inhibits various physiological functions (Monnet et al., 2001). It is important for many functions in plants such as photosynthesis, respiration, $\mathrm{CO}_{2}$ assimilation, ATP synthesis and nitrogen metabolism (Guo et al., 2010) and disease resistance (Tomazela et al., 2006).

Foliar spray with $\mathrm{Cu}$ to orange trees significantly increased fruit yield/ tree, fruit weight, and total soluble solids and fruit size as compared to the untreated trees (Khurshid et al., 2008). Spraying 'Rotabi seyah' table grape with $\mathrm{CuSO}_{4}$ at 25 or $50 \mathrm{ppm}$ recorded the highest TSS in berries than unsprayed (Eshghi et al., 2010). Also, Ilyas et al. (2015) reported that spraying orange with $\mathrm{Cu}$ at $0.1 \%$ significantly increased fruit weight, juice volume, number of fruit / tree than unsprayed. And Harris and Lavanya (2016) showed that the highest fruit weight, pulp weight of tomato, TSS and ascorbic acid were obtained with $\mathrm{Cu}$ as foliar spray at $250 \mathrm{ppm}$ than unsprayed plants. In addition, spraying grape vine with $\mathrm{Cu}$ at $1.0 \mathrm{~g} / \mathrm{l}$ recorded the highest values of Yields, 100 -fruit weights, fruit lengths, soluble solids, vitamin $\mathrm{C}$, soluble sugar, titratable acid and sugar acid ratio than unsprayed of grape plants (Zhiguang et al., 2019).

The merit of this study was testing the benefits of spraying orthophosphoric acid and copper sulphate on Red Roomy grapevines.

\section{Materials and Methods}

In a private vineyard located at Aga district, Dakahlia Governorate, forty-two head trained Red Roomy grapevines 17 years old were selected for carrying out this experiment during 2018 and 2019 seasons. At pruning time (mid. Jan.) 72 buds were left per each vine. Full description of the tested soil is given in Table (1).

A randomized complete block design was used in the present study where the following seven treatments were included:

1- Control (sprayed with tap water).

2- Spraying orthophosphoric acid at $0.1 \%$.

3- Spraying orthophosphoric acid at $0.2 \%$.

4- Spraying copper sulphate at $0.1 \%$.

5- Spraying copper sulphate at $0.2 \%$.

6- Spraying orthophosphoric acid + copper sulphate each at $0.1 \%$.

7- Spraying orthophosphoric acid + copper sulphate $0.2 \%$.

Table 1: Analysis of the tested soil

\begin{tabular}{lc}
\hline Particle size distribution :- & \\
\hline Sand \% & 7.0 \\
Silt \% & 75.0 \\
Clay \% & 18.0 \\
Texture : & silly loam \\
pH (1:2.5 extract) & 8.0 \\
E.C. ( 1:2.5 extract) & $0.62 \mathrm{~d} \mathrm{sra}^{11}$ \\
0. M. \% & 1.9 \\
Ca CO3 & 1.5 \\
Total N \% & 0.23 \\
P(Olsen, ppm) & 62.2 \\
K (ammonium acetate, ppm) & 390.0 \\
\hline DTPA extractable micronutrients (ppm) & \\
Fe & 22.0 \\
Zn & 10.9 \\
Cu & 11.0 \\
Mn & 14.0 \\
\hline
\end{tabular}

Spraying of both fertilizers was done four times at growth start (mid. April.), first bloom (mid. May), berry set (mid. June.) and 30 days later (mid. July.). Triton B as a wetting agent at $0.1 \%$ was added to all solutions and tap water (for control vines). The vines were sprayed till run off. Regular agricultural practices were done as usual. Each treatment was replicated three times two vines per each. 
Berry set percentage was estimated by dividing the number of set berries/cluster by total number of flowers in each caged cluster and multiplying the product by 100 .

At harvesting date (mid- Sept.), the yield of each vine was, recorded in terms of number of clusters and weight $(\mathrm{kg})$, then the average berry weight (g.) as well as total soluble solids $\%$ and total acidity $\%$ (expressed as g. of tartaric acid $/ 100 \mathrm{~g}$ juice) according to A.O.A.C. (2000) were determined.

Statistical analysis was done according to Mead et al. (1993) using L.S.D parameter at $5 \%$ level.

\section{Results and Discussion}

\section{Berry set, yield and number of clusters}

Data recorded in Tables (2 and 3) clearly show that foliar application of orthophosphoric acid and/or copper sulphate caused significant increase in berry set, yield and number of clusters (in the second season) compared unsprayed vines. Combined application of such two fertilizers surpassed the single application of each fertilizer.In this connection, number of clusters in the first season of study did not alter with the application of both fertilizers singly or in combinations. The significance was absent due to raising the concentrations of each compound from 0.1 to $0.2 \%$.As a general, spraying orthophosphoric acid was preferable than the application of copper sulphate in improving berry set, yield and number of cluster. Economically point of view, spraying of these two fertilizers together at $0.1 \%$ resulted in the highest yield. Berry set was 8.5 and $8.8 \%$ while yield reached 16.25 and $18.13 \mathrm{~kg}$ in vines treated with such striking treatment in both seasons, respectively. These results were true in both seasons.

Table 2: Effect of foliar application of orthophosphoric acid and copper sulphate on berry set, yield and its components of Red Roomy grapes in 2018 season.

\begin{tabular}{|c|c|c|c|c|c|c|}
\hline Treatments & $\begin{array}{c}\text { Berry } \\
\text { set } \\
\%\end{array}$ & $\begin{array}{l}\text { Berry } \\
\text { weight } \\
\text { (g.) }\end{array}$ & $\begin{array}{c}\text { No. of } \\
\text { clusters per } \\
\text { vine }\end{array}$ & $\begin{array}{c}\text { Cluster } \\
\text { weight } \\
\text { (g.) }\end{array}$ & $\begin{array}{c}\text { Yield / } \\
\text { vine (kg.) }\end{array}$ & Relative \\
\hline Control ( untreated vines ) & 6.1 & 4.2 & 31.0 & 276.3 & 8.57 & 100.0 \\
\hline Orthophosphoric acid at $0.1 \%$ & 7.4 & 5.7 & 31.0 & 441.8 & 13.70 & 159.9 \\
\hline Orthophosphoric acid at $0.2 \%$ & 7.5 & 5.8 & 30.0 & 445.0 & 13.35 & 155.8 \\
\hline Copper sulphate at $0.1 \%$ & 6.7 & 4.9 & 30.0 & 348.0 & 10.44 & 121.8 \\
\hline Copper sulphate at $0.2 \%$ & 6.7 & 5.0 & 30.0 & 351.0 & 10.53 & 122.9 \\
\hline $\begin{array}{l}\text { Orthophosphoric acid + } \\
\text { Copper sulphate at } 0.1 \%\end{array}$ & 8.0 & 6.3 & 31.0 & 524.3 & 16.25 & 189.6 \\
\hline $\begin{array}{l}\text { Orthophosphoric acid + } \\
\text { Copper sulphate at } 0.2 \%\end{array}$ & 8.2 & 6.4 & 31.0 & 526.2 & 16.31 & 190.3 \\
\hline L.S.D at $\quad 5 \%$ & 0.4 & 0.3 & NS & 7.3 & 1.11 & \\
\hline
\end{tabular}

Table 3: Effect of foliar application of orthophosphoric acid and copper sulphate on berry set, yield and its components properties of Red Roomy grapes in 2019 season.

\begin{tabular}{lcccccc}
\hline Treatments & $\begin{array}{c}\text { Berry } \\
\text { set } \\
\text { \% }\end{array}$ & $\begin{array}{c}\text { Berry } \\
\text { weight } \\
\text { (g.) }\end{array}$ & $\begin{array}{c}\text { No. of } \\
\text { clusters per } \\
\text { vine }\end{array}$ & $\begin{array}{c}\text { Cluster } \\
\text { weight } \\
\text { (g.) }\end{array}$ & $\begin{array}{c}\text { Yield / } \\
\text { vine (kg.) }\end{array}$ & Relative \\
\hline Control ( untreated vines ) & 6.5 & 4.0 & 29.0 & 280.2 & 8.13 & 100.0 \\
Orthophosphoric acid at 0.1 \% & 8.2 & 5.8 & 35.0 & 450.3 & 15.76 & 193.8 \\
$\begin{array}{l}\text { Orthophosphoric acid at 0.2 \% } \\
\text { Copper sulphate at 0.1 \% }\end{array}$ & 8.2 & 5.9 & 35.5 & 451.0 & 15.79 & 194.2 \\
$\begin{array}{l}\text { Copper sulphate at 0.2 \% } \\
\text { Orthophosphoric acid + }\end{array}$ & 7.0 & 4.5 & 32.0 & 441.0 & 14.11 & 173.6 \\
$\begin{array}{l}\text { Copper sulphate at 0.1\% } \\
\text { Orthophosphoric acid + }\end{array}$ & 8.0 & 4.6 & 32.3 & 442.0 & 14.28 & 175.6 \\
Copper sulphate at 0.2 \% & 8.8 & 6.4 & 37.0 & 490.0 & 18.13 & 223.0 \\
\hline L.S.D at 5\% & 8.8 & 6.5 & 37.3 & 493.0 & 18.39 & 226.2 \\
\hline
\end{tabular}

The improving influence of $\mathrm{P}$ and $\mathrm{Cu}$ on enhancing the biosynthesis of organic foods consequently raising vine nutritional status in favour of producing more flowers could explain their 
positive effect on berry set. The great benefits of these nutrients on producing more flower clusters were reflected on increasing the yield.

These results are in agreement with those obtained by Youssef (1997) on Red Roomy grapevines and Ilyas et al. (2015) who found spraying orange with $\mathrm{Cu}$ at $0.1 \%$ significantly increased number of fruits / tree than unsprayed. Also, Noori et al. (2018) showed that spraying grape with phosphorus at $10 \mathrm{~g} / 1$ were the best treatment for enhancing cluster number and cluster weight, fruit number / cluster than $5 \mathrm{~g} / 1$ or unsprayed.

\section{Weights of cluster and berry}

It is evident from the data in Tables (2 and 3) that single or combined application of orthophospharic acid and copper sulphate at 0.1 to $0.2 \%$ was followed by a significant increment in weights of cluster and berry compared with un-spraying these two compounds, also raising their concentrations from 0.1 to 0.2 failed to show any measurable and significant effect on weights of cluster and berry. Foliar application of orthophosphoric acid was superior also the application of copper sulphate. In this connection the combined application of both gave satisfactory improvement in weights of cluster and berry compared with the single spray of each. The maximum values were obtained on vines sprayed with orthophosphoric acid with copper sulphate each at $0.1 \%$.

The relative increases in yield / vine were about 89.6 and $123.0 \%$ for spraying orthophosphoric acid with copper sulphate each at $0.1 \%$ than unsprayed vines in the 2018 and 2019 seasons, respectively. These results were true in both seasons.

The positive effect of $\mathrm{P}$ and $\mathrm{Cu}$ on duster weight was attributed to their enhancing effect on berry set previously mentioned in the later discussion. The stimulating effect of them on cell division and cell enlargement could explain their action on berry weight. The increase in berry weight also gave a logical explanation for their positive action on cluster single.

These findings are in harmony with those obtained by Mohamed (1992) on Anna apple and Singh et al. (2005) on mango tree regarding the effect of orthophosphoric and Youssef (1997) and Zhiguang et al. (2019) on grape respecting $\mathrm{Cu}$ effect.

\section{Total soluble solids and total acidity}

It is clear from the data in Table (4) that treating Red Roomy grapevines with orthophosphoric acid and copper sulphate either singly or in combinations significantly improved chemical quality in terms of increasing total soluble solids and reducing the total acidity compared with unsparing vines. Varying the concentrations of both compounds from 0.1 to $0.2 \%$ was effect on such chemical traits. Application of orthophosphoric acid at 0.1 to $0.2 \%$ surpassed the application of copper sulphate in enhancing the chemical quality of the berries.

Table 4: Effect of foliar application of orthophosphoric acid and copper sulphate on TSS and total acidity of Red Roomy grapes in 2018 and 2019 seasons.

\begin{tabular}{|l|c|c|c|c|}
\hline \multirow{2}{*}{ Treatments } & \multicolumn{2}{|c|}{$\begin{array}{c}\text { T.S.S. } \\
\text { \% }\end{array}$} & \multicolumn{2}{c|}{ Total acidity } \\
\%
\end{tabular}

The best results with regard to chemical quality of the berries were obtained due to the application of both fertilizers together at $0.1 \%$. Similar results were obtained in (2018) and (2019) seasons. 
Such improvement in quality of berries could be due to the effect of $\mathrm{P}$ and $\mathrm{K}$ in advancing fruit ripening through their effects on biosynthesis and translocation of sugars (Nijjar, 1985).

These results are in agreement with those obtained by Saleh et al. (2007) on Thompson seedless grape, Eshghi et al. (2010) on Rotabi Seyah Table grape. In this concern, Noori et al. (2018) showed that spraying grape with phosphorus at $10 \mathrm{~g} / 1$ were the best treatment for enhancing TSS and total acidity in berries than $5 \mathrm{~g} / 1$ or without spray. In addition, spraying grape vine with $\mathrm{Cu}$ at $1.0 \mathrm{~g} / 1$ recorded the highest values of soluble solids, vitamin $\mathrm{C}$, soluble sugar, titratable acid and sugar acid ratio than unsprayed plants (Zhiguang et al., 2019).

Finally, under the same conditions, it could be concluded that, according to the obtained results , the best treatment for increasing yield and its components and enhancing berries quality was spraying orthophosphoric acid in combined with copper sulphate four times at $0.1 \%$ per each.

\section{References}

A.O.A.C., 2000. Association of Official Agricultural Chemists. $17^{\text {th }}$ Ed. A.O.A.C., Wash., D.C.

Asad, A.S., Nagwa A. Abd El-Megeed and E.S. Atalla, 2013. Effect of foliar application of micronutrients on Le-Conte pear trees under calcareous soil condition. J Am Sci., 9 (7):123-128.

Davarpanah S., M. A. Aakari, M. Babalar, M. Zarei, R. Nazary and M. Aghayeh, 2017. Effect of Foliar Application of Phosphorus, Potassium and Iron on Physical and Chemical Properties of Pomegranate Fruit. Jordan J. Agric. Sci., 13(3):693-706.

Eshghi, S., B. Kavoosi and M.H. Farehi, 2010. Influence of streptomycin and $\mathrm{CuSO}_{4}$ on seedless and fruit quality in Rotabi Seyah table grape. Inter. Soc. Hort. Sci., (88) 461-466.

Guo, X.Y., B.Y. Zuo, B.R. Wang and Y.B. Ma, 2010.Toxicity and accumulation of copper and nickel in maize plants cropped on calcareous and acidic field soils. Plant and Soil, 333:365-373.

Harris K.D. and L. Lavanya, 2016. Influence of Foliar Application of Boron, Copper and their Combinations on the quality of Tomato (Lycopersicon esculentum Mill.). Res. J. Agriculture and Forestry Sci., 4(7):1-5.

Havlin, J. L., J. D. Beaton, S.L. Tisdale, and W.L. Nelson, 2005. Soil Fertility and Fertilizers: $7^{\text {th }}$ edn.An Introduction to Nutrient Management. Upper Saddle River, New Jersey, U. S. A.

Ilyas A., M.Y. Ashraf, M. Hussain, M. Ashraf, R. Ahmed and A. Kamal, 2015. Effect of micronutrients $(\mathrm{Zn}, \mathrm{Cu}$ and $\mathrm{B})$ on photosynthetic and fruit yield attributes of Citrus reticulata Blanco Var. Kinnow. Pak. J. Bot., 47(4): 1241-1247.

Khurshid, F., R.A. Khattak and S. Sarwar, 2008. Effect of foliar applied (Zn, Fe, Cu \& Mn) in citrus production. Science Technology \& Development, 27: 34-42.

Maksymiec, W., 1997. Effect of copper on cellular processes in higher plants. Photosynthetic, 34:321342.

Mead, R., R.N. Curnow and A.M. Harted, 1993. Statistical Methods in Agriculture and Experimental. Biology $2^{\text {Ed. }}$ Chapman \& Hall, London.

Mohamed, M. A., 1992. Anna apple cultivar productivity as influenced by foliar sprays of potassium nitrate and orthophosphoric acid. Minia J. Agric. Res. \& Dev., 14 (1): 98 -115.

Monnet, F., N. Vailant, P. Vernay, A. Coudret, H. Sallanon and A. Hitmi, 2001. Relationship between PSII activity, $\mathrm{CO}_{2}$ fixation and $\mathrm{Zn}, \mathrm{Mn}$ and $\mathrm{Mg}$ contents of Lolium perenne under zinc stress. Journal of Plant Physiology, 158:1137-1144.

Nijjar, G. S., 1985. Nutrition of Fruit Trees. Mrs. Usha Raj i Kumar, Kalyani, New Delhi, India, pp $10-20$.

Noori A.M., M.A. Lateef and M.H. Muhsin, 2018. Effect of phosphorus and gibberellic acid on growth and yield of grape (Vitis vinifera L.). Res. on Crops, 19(4): 643-648.

Saleh, M.M.S., N.E. Ashour, M. EL- Sheikh and M.A.A. EL-Naggar, 2007. Foliar sprays of potassium dihydrogen phosphate and their impact on yield, fruit quality and controlling Powdery Mildew disease of Thompson seedless grapevines . American- Eurasian J. Agric. \& Environ. Sci., 2(2), 133-140

Singh, N.P, C.S. Malhi and R.C. Sharam, 2005. Effect of foliar feeding of N, P and K on vegetative and fruiting characters of Mango cv. Dusehri. Proceedings Inter. Conf. on mango and date Palm: culture and Export.20 $0^{\text {th }}-23^{\text {rd }}$ June. $27-31$. 
Tomazela, A.L., J.L. Favarin, A.L. Fancelli, T.N. Martin, D. Dourado Net, and R.R.D. Reis, 2006. Rates of Nitrogen and Sources of Supplementary $\mathrm{Cu}$ and $\mathrm{Mn}$ on the Severity of the Rust and Morphologic Attributes. Revista Brasileira De Milho E Sorgo, 5:192-201

Ustun, N. S. and I. Tosun, 1997. The composition of pekmez. Gida, $22: 417-23$.

Youssef, W.S., 1997. Effect of spraying mepiquat chloride and some macro and micronutrients on growth, yield and quality of Red Roomy grapevines (Vitis vinifcra L.) Ph.D Thesis Fac. Agric. El-Minia Univ. Egypt.

Zhiguang L., C. Haining, C.L. Yuncong, S. Yao, M. Qiang and Z. Chenhao, 2019. Effects of foliar application of the mixture of copper and chelated iron on the yield, quality, photosynthesis, and microelement concentration of table grape (Vitis vinifera L.). Scientia Horticulturae, 254, : 106115. 